\title{
Tradisjon og fornyelse
}

I år er det 20 år siden Tidsskriftet ble lansert på internett, i februar 1996 (1). Vi var tidlig ute - det skjedde bare noen måneder etter at $B M J$ var blitt verdens første generelle medisinske tidsskrift på nettet (2). De aller første søkemotorene kom samme år, og World Wide Web var blitt lansert fem år før, i 1991 (3). Det var ikke så mange potensielle lesere den gang - i 1995 brukte bare $5 \%$ av befolkningen internett ukentlig (4). Men selv uten søkemotorer fant de få legene med nettilgang raskt frem til tidsskriftet.no: Etter bare to måneders drift besøkte et femtitalls brukere Tidsskriftets hjemmesider hver dag (5).

Resten er som kjent historie. I dag har $96 \%$ av befolkningen i Norge tilgang til internett, og $88 \%$ bruker det daglig (6). Tidsskriftet henger med: Omkring 65000 unike brukere besøker nå våre nettsider ukentlig, der de generer opptil 110000 ukentlige sidevisninger. Tidsskriftet synes godt på internett. Men sterk synlighet forplikter. Skal norske leger fortsette å benytte Tidsskriftets nettsider like ivrig som nå, må de tilbys et tidsriktig digitalt produkt. 13. september 2016 tar Tidsskriftet derfor et nytt og viktig skritt i sin digitale utvikling og lanserer nye nettsider og ny logo.

Den nye logoen inneholder en stilisert versjon av asklepiosstaven, det fremste symbolet for legekunsten. Dette signaliserer en sterkere identitet for Tidsskriftet, samtidig som den med underteksten kommuniserer vårt ståsted og vår eier. Fonten som er valgt til tekstelementene er spesialdesignet og er ment å signalisere både tradisjon og fornyelse, slik Tidsskriftet må skue både bakover og fremover. Fra og med Tidsskriftet nr. 17/2016 vil du finne den samme logoen på papirutgavens forside.

Med de nye nettsidene ønsker vi å gi en optimal leseropplevelse - på både stor skjerm, nettbrett og mobiltelefon. Dette siste er ikke minst viktig. Inntil nå har vår nettversjon ikke vært tilpasset mobiltelefon, selv om $60 \%$ av trafikken på internett i Norge kommer fra mobiltelefon (7) og 92\% av befolkningen i aldersgruppen 20-39 år bruker mobilt medieinnhold ukentlig (8). Her er det ingen grunn til å tro at leger er annerledes enn andre. Derfor må Tidsskriftet tilby en god leseropplevelse på telefonen. Fra og med i dag mener vi å kunne det. Som konsekvens av at våre nye nettsider automatisk også tilpasser seg alle typer nettbrett, legger vi ned iPad-versjonen. Denne løsningen er blitt gradvis mindre benyttet av leserne, i takt med at flere og flere foretrekker vanlige nettsider også på nettbrett og egne iPadversjoner av tidsskrifter generelt er blitt mindre vanlig.
Å publisere deler av innholdet først på nett har Tidsskriftet gjort helt siden 2004 (9). Med de nye nettsidene blir dette gradvis utvidet til å gjelde alt innhold. Som leser vil du derfor få innholdet raskere, og som forfatter vil du nå raskere ut. For mange leger er det fortsatt papirutgaven som «er» Tidsskriftet. Derfor er det et viktig poeng at den nye og moderne nettplattformen også gir oss større muligheter til å videreutvikle papirutgaven på dens egne premisser. For papirutgaven er mye lest og vil fortsatt være viktig.

Alle artiklene i Tidsskriftets komplette digitale årganger, til sammen over 25000 enkeltartikler, er importert til de nye nettsidene, som inneholder en lang rekke nye funksjonaliteter. En så omfattende oppgradering vil gi opphav til barnesykdommer. Selv etter lanseringen vil det utvilsomt finnes både forbedringspotensialer og direkte feil. Noen av dem vil vi finne selv. Men de aller fleste vil leserne finne gjennom daglig omgang med nettsidene. I redaksjonen ønsker vi oss tilbakemeldinger om stort og smått som kan fungere bedre. La oss høre om de feilene dere finner, gjerne i form av en e-post til redaksjonen@tidsskriftet.no. Bare slik kan kvaliteten og leseropplevelsen bli så optimal som vi ønsker oss og Tidsskriftet fortsatt det samlende element for alle norske leger (10). «Vi imøteser med spenning tilbakemeldinger», skrev Magne Nylenna da Tidsskriftets første internettversjon ble lansert i 1996 (1). Det ønsket står seg fremdeles.

\footnotetext{
Litteratur

1. Nylenna M. Tidsskriftet på Internett. Tidsskr Nor Lægeforen 1996; 6: 778.

2. Delamothe T. BMJ on the internet. BMJ 1995; 310: 1343-4.

3. Wikipedia. no. Internett. https://no.wikipedia.org/wiki/Internett (4.9.2016) Haga SG. Internett øker mest. Dagbladet 16.4.1998.

5. Nicolaysen KG. Tidsskriftet - med to måneders fartstid på Internett. Tidsskr Nor Lægeforen 1996; 14: 1712.

6. Futsæter KA. De store medietrendene. www.tns-gallup.no/medier (4.9.2016)

7. Michalsen GL. Veksten i mobiltrafikk har begynt å avta, og lite tyder på at desktop «dør» med det første. www.medier24.com/nyheter/veksten-i-mobiltrafikk-harbegynt-a-avta-og-lite-som-tyder-pa-at-desktop-dor-med-det-forste/ (4.9.2016).

8. Mobilrapporten «Bruk av mobilt medieinnhold» Q1/2016. www.tns-gallup.no/ medier/nyheter (4.9.2016).

9. Haug C. Viktig sak - først på nett. Tidsskr Nor Lægeforen 2004; 124: 2325.

10. Brean A. At rede og at ordne. Tidsskr Nor Legeforen 2015; 135: 1007.
}

ab Engelsk oversettelse på www.tidsskriftet.no 